Original Paper

\title{
耐水性を有する新規応力発光材料の開発
}

\section{Development of a Novel Mechanoluminescent Material with Water-Resistance}

\author{
張 琳 ${ }^{\mathrm{a}}$, 山田 浩志 ${ }^{\mathrm{b}}$, 今井 祐介 ${ }^{\mathrm{b}}$, 寺崎 正 $^{\mathrm{b}}$, \\ Lin Zhang, Hiroshi Yamada, Yusuke Imai, Nao Terasaki, \\ 安達 芳雄 ${ }^{\mathrm{b}}$, 西久保 桂子 ${ }^{\mathrm{b}}$, 徐 超男 ${ }^{\mathrm{a}, \mathrm{b}, \mathrm{c}}$ \\ Yoshio Adachi, Keiko Nishikubo, Chao-Nan Xu
}

\begin{abstract}
Received 14 March 2007; Accepted 30 May 2007
Mechanoluminescence (ML) materials have attracted lots of attention due to the potential application in novel stress indicators. $\mathrm{SrAl}_{2} \mathrm{O}_{4}: \mathrm{Eu}^{2+}$ (SEAO) that exhibits green emission is a well-known $\mathrm{ML}$ material. However the ML performance would markedly be degraded when it is put into water environment due to a hydrolysis reaction. In this study we have synthesized a novel ML material, calcium aluminosilicate doped with europium $\left(\mathrm{CaAl}_{2} \mathrm{Si}_{2} \mathrm{O}_{8}: \mathrm{Eu}^{2+}\right)$ using the solid state reaction process. $\mathrm{X}$ - ray diffraction, photoluminescence and mechanoluminescence were measured to characterize the crystallinity and optical properties. The developed ML material showed a strong resistance to water compared to SEAO. It was shown that the introduction of $\mathrm{SiO}_{4}$ tetrahedra leads to the water resistance of calcium aluminosilicate.
\end{abstract}

Keywords : Mechanoluminescence, Strontium aluminate, Calcium aluminosilicate, Water resistance

\section{1. 緒 言}

応力発光 (Mechanoluminescence, ML) とは, 一 般に, 摩擦, 衝撃, 圧縮, 引張りなど外部から加えら れる機械的な作用によって発光する現象を指す。この ような現象は古く中世の頃から認識されており，ル ネッサンス期に活躍したイギリスの哲学者フランシ ス・ベーコンの著作中にも，結晶化した砂糖を暗闇で 砕いた時に発光が観察されたとの記述が残されてい る ${ }^{1)}$ 。また，地震が起きた際にそれと前後して夜空が

a 九州大学総合理工学府 物質理工学専攻

（テ816-8580 福岡県春日市春日公園 6-1）TEL 092-582-7547

Department of Molecular and Material Science of Interdisciplinary, Graduate School of Engineering Science, Kyushu University

(6-1 Kasugakoen, Kasuga, Fukuoka 816-8580, Japan)

b 産業技術総合研究所 九州センター

（テ841-0052 佐賀県鳥栖市宿町807- 1）TEL 0942-81-3661

National Institute of Advanced Industrial Science and

Technology (AIST)

(807-1, Shuku-machi, Tosu, Saga 841-0052, Japan)

c 科学技術振興機構

（T332-0012 埼玉県川口市本町 4) TEL 048-226-5601

CREST, Japan Science and Technology Corporation

(JST) Agency

(Honcho 4. Kawaguchi, Saitama 332-0012, Japan)
ほのかに光り照らされる現象が以前から観測されてい るが, これも地盤の破壊に伴う応力発光と関係してい ると言われており, 地震前兆の予知信号として地震予 知研究者から注目されている ${ }^{2)}$ 。このような発光現象 は普通，破壊や摩擦といった物質の破壊的カタスト口 フィーを伴った現象であり破壊発光と呼ばれている。 破壊発光は，無機物質の約半分，有機物質の三分の一 が示すと言われており，非常に一般的な現象であ る $^{3)}$ 。一方で, 破壊を伴わない応力発光は変形発光之 呼ばれており，このような発光を示す材料は非常に限 られている。変形発光は材料の変形領域に応じてさら に塑性変形発光と弾性変形発光に分類でき，前者の例 として放射線照射したアルカリハライドなどが報告さ 扎いるが4), 弾性変形によって発光する材料は理論 モデルとしては提唱されていたものの，1990年代後 半まで実現はされてこなかった。また，この時点まで の応力発光の研究は, 材料自体の物性に注目したもの ばかりで，応力発光現象をセンサなどに応用しようと いう試みは，我々の画期的な提案まで日の目を見るこ とはなかった。我々は，压電体や歪みゲージを利用し た既存の力計測が，限られた領域の点測定であり，空 
間分解能はセンサ素子の大きさに限定されること，配 線が煩わしく対象物の計測を簡便にできないことに問 題点を見出し，その解決策として光による力計測とい う全く新しいコンセプトを提案した ${ }^{5.6)}$ 。この提案を 実現する上でキーとなるのが弾性変形による応力発 光である。しかしながら，先に述べたように弾性変 形による発光はこれまで報告されておらず，材料その ものから開発しなければならなかった。我々はもとも と圧電体の誘起電場によって LED (Light Emitting Diode）を発光させる研究を行っていたことから，そ の延長として圧電体自体に発光中心を入れ光らせると いう発想のもと，压電材料之発光中心である希土類・ 遷移金属イオンとの組み合わせから，弾性領域でも発 光を示す応力発光体の開発に成功した ${ }^{7 \sim 10)}$ 。開発され た応力発光体は非常に微弱な力でも目視可能な発光を 示し, 発光強度が加えられた歪みエネルギーと線形的 な関係にあることからセンサとしての高い可能性を有 している ${ }^{11)}$ 。応力発光体を利用したセンサ技術は，既 存の圧力センサ技術と比較して次のような利点を有し ている。応力発光体は単一粒子でもセンシング機能を 有していることから，マイクロ領域の応力を検出する ことが可能であり，さらに，塗膜として部材表面に コーティングすることにより，比較的大面積の応力分 布も発光分布としてCCD カメラ (Charge Coupled Device camera）などで簡便に記録することが可能で

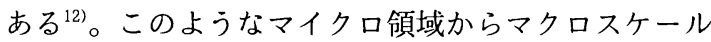
の構造体までカバーするマルチスケール・センシング という特色は, 既存のセンサにはない絶対的優位性を 有しており, 現在このような応力発光体の特色を生か した様々な応力センシング技術の研究開発が我々のグ ループ中心に進められている。

これまでに開発されてきた応力発光体の中で一番 実用化に近い材料として, 発光中心にユウロピウム を添加した欠陷制御型アルミン酸ストロンチウム $\left(\mathrm{SrAl}_{2} \mathrm{O}_{4}: \mathrm{Eu}^{2+}, \mathrm{SEAO}\right)$ がある ${ }^{10)}$ 。SEAO 発光体はこ れまで開発されてきた応力発光体の中で最も輝度が高 く, 目視でもその発光が確認できることから，実用化 に向けた製品開発が進められているが，耐水性に問題 を抱えている。すなわち，SEAO は水との反応性が 高く, 粒子が水に接するとすぐに加水分解が始まり, 粒子表面から結晶構造が徐々に崩壊していく現象が観 測されている。発光性能はそれに伴い低下していき, 最終的には水酸化物へと分解してしまい発光は全く示 さない ${ }^{133}$ 。SEAO の耐水性の改善策として，表面を燐 酸やシリカでコーティングする技術が開発され，飛躍

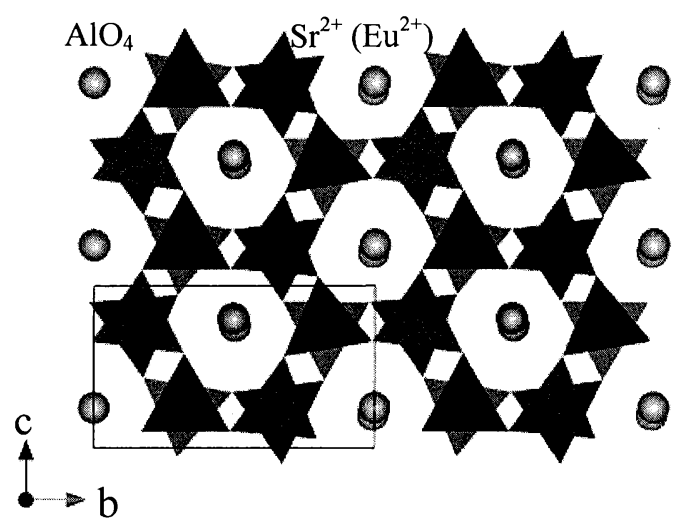

Fig. 1 The crystal structure of $\mathrm{SrAl}_{2} \mathrm{O}_{4}: \mathrm{Eu}^{2+}$ phosphor

的な耐水性の向上が実現しているが(14)，製造プロセス の簡素化という観点から, 直接耐水性を有する応力発 光材料の創製が望まれている。

新規応力発光材料の開発指針として, SEAO と類 似の母体構造を有する材料群から材料探索することが 有望である。SEAO の結晶構造を Fig. 1 に示す。結晶 構造の特徵として, $\mathrm{AlO}_{4}$ 四面体が頂点酸素を共有し 3 次元的に連結していることにより，比較的大きな空 間を有するフレームワーク構造を形成している。 $\mathrm{Sr}^{2+}$ はこの隙間に電荷補償として挿入されており, 発光中 心として固溶させた $\mathrm{Eu}^{2+}$ イオンも $\mathrm{Sr}^{2+}$ と同じ結晶学 的なサイトに置換されていると考えられている。ま た，SEAOの母体構造は室温で単斜晶系に属してお り対称性が低い。この対称性を反映して結晶内部には 大きな自発歪みが存在しており, 強弾性体として振舞 うことが知られている ${ }^{15)}$ 。応力発光のメカニズムには まだ不明の点も多いが，このような構造的特徵を有す る材料は外部応力に対して歪みやすいと考えられ， 応力場の発光中心への伝達効率が非常に高いと予想さ れる。アルミノケイ酸塩蛍光体 $\left(\mathrm{CaAl}_{2} \mathrm{Si}_{2} \mathrm{O}_{8}: \mathrm{Eu}^{2+}\right.$,

CEAS）は，紫外光励起に対して青色発光を示す蛍光 体としてょく知られているが(16)，その母体構造は Fig. 2 に示すようにSEAO と類似な構造を持ち，応力発 光体の母体構造として有望である。SEAO の結晶構 造と異なる点は, 3 次元フレームワーク構造を形成し ている構成単位が $\mathrm{AlO}_{4}$ 四面体だけでなく, $\mathrm{SiO}_{4}$ 四面 体が $1: 1$ の割合で挿入されていること，また，結晶 対称性が SEAO よりもさらに低い三斜晶系に属して いることが挙げられる。ここで注目すべき点は，共有 結合性の高い $\mathrm{SiO}_{4}$ 四面体が構造中に加わることによ り, フレームワーク構造がより強固であり耐水性の改 


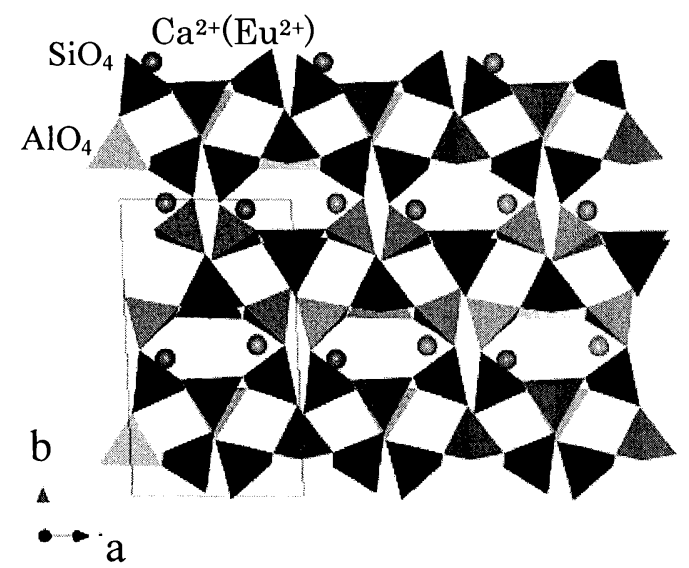

Fig. 2 The crystal structure of $\mathrm{CaAl}_{2} \mathrm{Si}_{2} \mathrm{O}_{8}: \mathrm{Eu}^{2+}$ phosphor

善が見込まれる点である。

本稿では，アルミノケイ酸塩を母体構造として持つ この青色蛍光体が高輝度の応力発光を示すことを明ら かにし，耐水性に関しても非常に優れた特性を有して いることを, SEAO との比較実験を参照しながら述 べる。

\section{2. 実 験}

\section{1 試料合成}

試料は固相反応法により合成した。原料には, $\mathrm{CaCO}_{3}$ (99.99\%), $\mathrm{Al}_{2} \mathrm{O}_{3}$ (99.99\%), $\mathrm{SiO}_{2}$ (99.9\%), $\mathrm{Eu}_{2} \mathrm{O}_{3}$ (99.9\%) を使用し, $\mathrm{Ca}_{0.98} \mathrm{Eu}_{0.02} \mathrm{Al}_{2} \mathrm{Si}_{2} \mathrm{O}_{8}$ の組 成比となるように秤量したのち，エタノール中で十 分混合し, 空気中 $50{ }^{\circ} \mathrm{C}$ で乾燥させた。得られた混 合物は，還元雰囲気中 $\left(\operatorname{Ar} 95 \%+\mathrm{H}_{2} 5 \%\right)$ において $1400{ }^{\circ} \mathrm{C} ， 3$ 時間焼成した。焼成後に得られた材料は 乳鉢で軽く粉砕し, 応力発光体の粉末材料として用い た。

\section{2 試料評価}

調製した試料は，まずX線回折装置（XRD，X-ray Diffractometer, 理学電機 RINT2000 型) によって 結晶構造を同定し，不純物相の有無を確認したのち, 分光蛍光光度計 (日本分光 FP-6600 型) を用いて光 学特性・発光特性 (Photoluminescence, PL) を評価 した。応力発光の評価には, 我々が独自に開発した 応力発光評価装置を用いた ${ }^{5.17)}$ 。応力発光 $(\mathrm{ML})$ 評価 用サンプルは円板形の試験片を用いており，これは 有機ポリマー中に粉末試料を均一分散させて成形（直 径 $25 \mathrm{~mm}$ ，高さ $11 \mathrm{~mm}$ ）し作製したものである。こ の円板の側面を材料試験機（オリエンテック RTC-

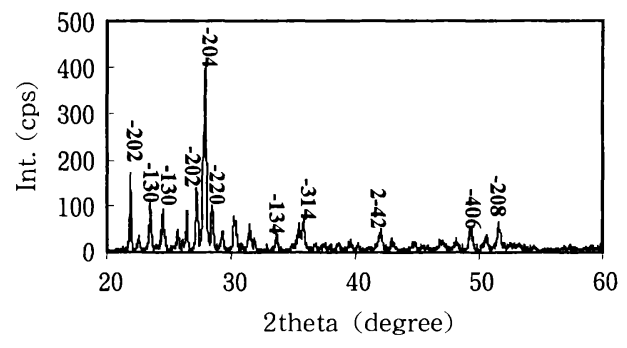

Fig. $3 \mathrm{X}$-ray diffraction pattern of $\mathrm{CaAl}_{2} \mathrm{Si}_{2} \mathrm{O}_{8}$

1310A）を用いて，一定速度 $(3 \mathrm{~mm} / \mathrm{min})$ で 0 から 最大 $1000 \mathrm{~N}$ の三角波形の圧縮応力を加え，応力発 光強度は光電子倍増管を用いたフォトカウンティン グシステム（浜松ホトニクスC5410）により計測し た。

\section{3 耐水性実験}

CEAS と SEAO の耐水性の比較実験は次のような プロセスの下で行った：(1)CEAS と SEAO それぞれ を蒸留水に所定時間含浸させた。(2)含浸時間は両者と も 0.5 時間， 1 時間， 5 時間， CEAS はさらに 10 日間 放置した。(3)それらを $50{ }^{\circ} \mathrm{C} ， 2$ 時間乾燥させた後回 収し, XRD, PL，走査型電子顕微鏡 (SEM, Scanning Electron Microscopy，日立 S-4300)，ML の各測定 により, 結晶性, 発光特性, 表面形状, 応力発光特性 を評価した。

\section{3. 結果及び考察}

\section{1 結晶構造, 発光特性, 及び応力発光評価}

応力発光の強度は不純物の有無に非常に敏感であ る。CEAS 粉末試料の XRD パターンを Fig. 3 に示す が，ICSD 無機結晶構造データベースを用いた回折 ピークの同定から不純物相の生成は確認できず, 三斜 晶系特有の XRD パターンのみが確認できた。従って, 添加した $\mathrm{Eu}^{2+}$ は母体マトリクスアにすべて固溶して

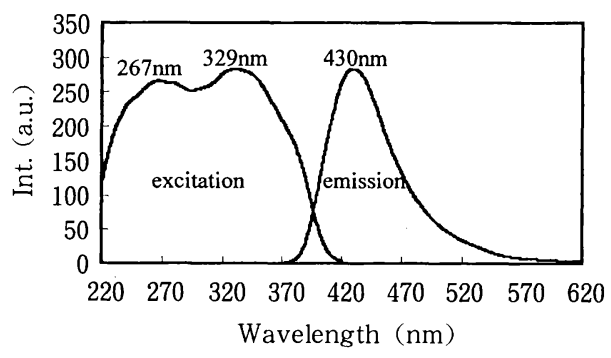

Fig. 4 Excitation and emission spectra of $\left(\mathrm{Ca}_{0.98} \mathrm{Eu}_{0.02}\right) \mathrm{Al}_{2} \mathrm{Si}_{2} \mathrm{O}_{8}$ 


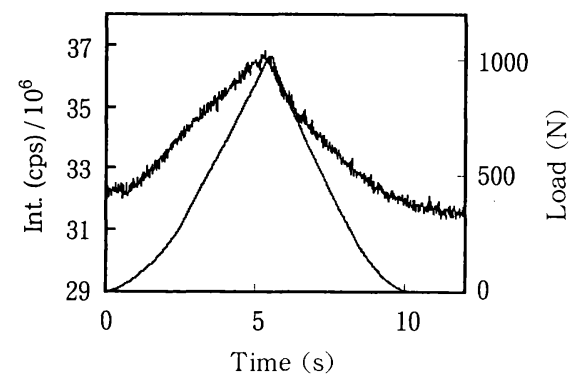

Fig. 5 Response curve of mechnoluminescence from $\left(\mathrm{Ca}_{0.98} \mathrm{Eu}_{0.02}\right) \mathrm{Al}_{2} \mathrm{Si}_{2} \mathrm{O}_{8}$

いると考えられ，イオン半径が最も近い $\mathrm{Ca}^{2+}\left(\mathrm{Ca}^{2+}\right.$ が 7 配位と仮定すると $\mathrm{r} \mathrm{Ca}^{2+}=1.06 \AA, \mathrm{r} \mathrm{Eu}^{2+}=1.20$ $\AA$ ）の位置に置換して入っていると考えられる。

次に, CEAS粉末試料の発光特性を評価するた め, 励起スペクトルおよび発光スペクトルを測定し た。結果はFig. 4 に示す。励起スペクトルには特徵的 な二つのブロードなピークが観測された。それぞれの ピーク位置は $267 \mathrm{~nm} と 329 \mathrm{~nm}$ であり，これは局在 中心として添加した $\mathrm{Eu}^{2+}$ の基底状態 $4 \mathrm{f}^{7}\left({ }^{8} \mathrm{~S}_{7 / 2}\right)$ か ら, $4 \mathrm{f}^{6} 5 \mathrm{~d}^{1}\left(\mathrm{e}_{\mathrm{g}}\right)$ と $4 \mathrm{f}^{6} 5 \mathrm{~d}^{1}\left(\mathrm{t}_{2 \mathrm{~g}}\right)$ への電子遷移に帰属で

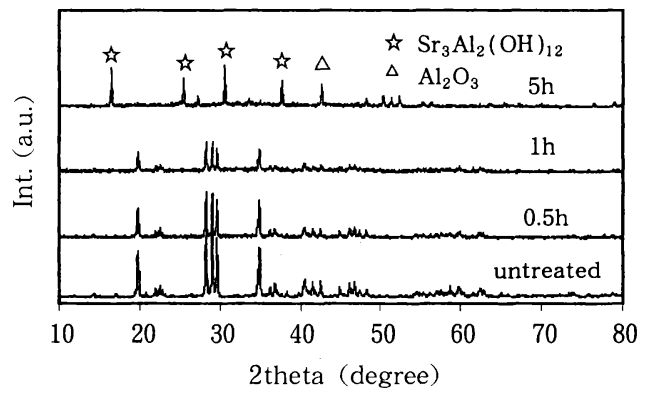

(a)

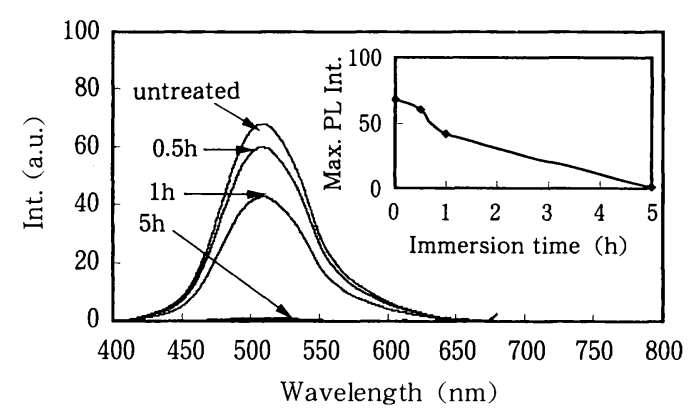

(b)

Fig. 6 Characterization of $\left(\mathrm{Sr}_{0.99} \mathrm{Eu}_{0.01}\right) \mathrm{Al}_{2} \mathrm{O}_{4}$ samples with various immersion time

a) X-ray diffraction patterns

b) emission spectra

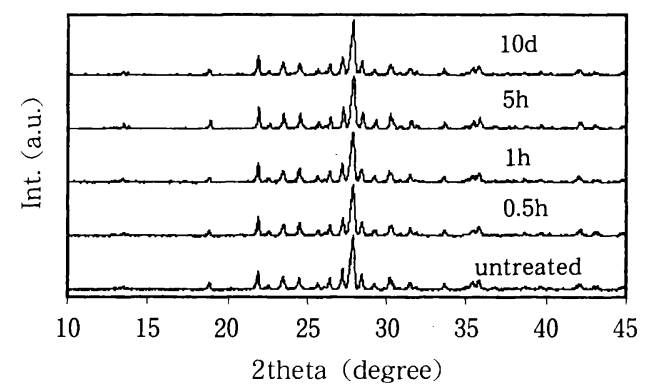

(a)

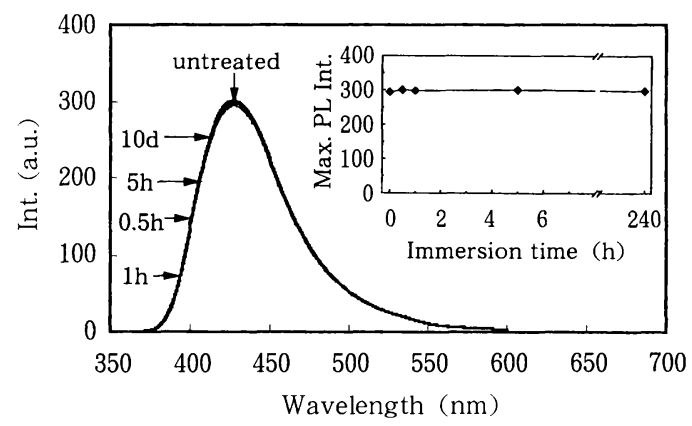

(b)

Fig. 7 Characterization of $\left(\mathrm{Ca}_{0.98} \mathrm{Eu}_{0.02}\right) \mathrm{Al}_{2} \mathrm{Si}_{2} \mathrm{O}_{8}$ samples with various immersion time

a) X-ray diffraction patterns

b) emission spectra

きると考えている。発光スペクトルは単一でブロード なピークが $430 \mathrm{~nm}$ に観測されており，これは $\mathrm{Eu}^{2+}$ の $4 \mathrm{f}^{6} 5 \mathrm{~d}^{1}\left(\mathrm{t}_{2 \mathrm{~g}}\right)-4 \mathrm{f}^{7}\left({ }^{8} \mathrm{~S}_{7 / 2}\right)$ 遷移に起因している。

最後に応力発光の応答曲線を Fig. 5 に示す。図から 明らかなように, 発光強度は応力の増大に応じて線形 的に増大しており, 印加応力が最大となる点で応力発 光も最大值に達した。これは, 弾性領域内の応力で励 起された発光現象であることを示唆している。

\section{2 耐水性の比較}

CEAS 耐水性の有無を確認するため, SEAO との耐 水性比較実験を行った。Fig. 6 に, 含浸前の SEAO 粉末試料と各所定時間蒸留水に含浸させた SEAO 粉 末試料の XRD パターンおよびPL スペクトルを示 す。図中には，PL スペクトルから見積もった PL 最 大值の含浸時間依存性を示している。図から明らかな ように, SEAO 粉末試料は含浸時間の増加に伴い, SEAO 由来の XRD ピーク強度が全体的に減少し, 5 時間含浸後にはSEAOの結晶構造は完全に消失し た。消失後の XRD パターンについて, ICSD 無機結 晶構造データベースを使用して解析した結果, 残留し ていた物質は水酸化ストロンチウムアルミニウムとア 


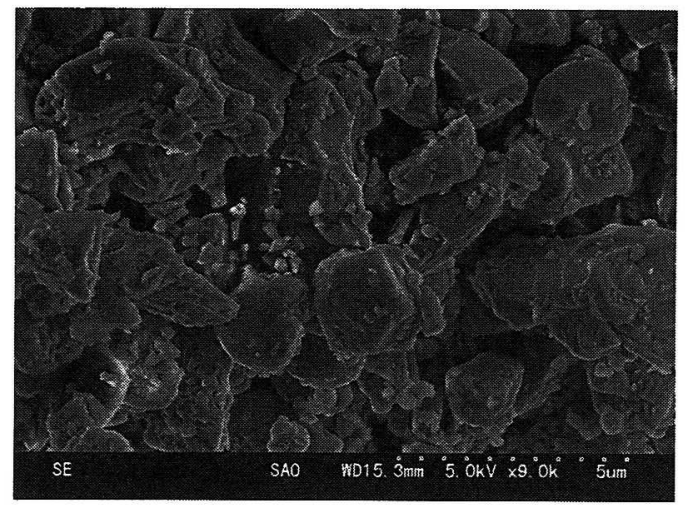

(a)

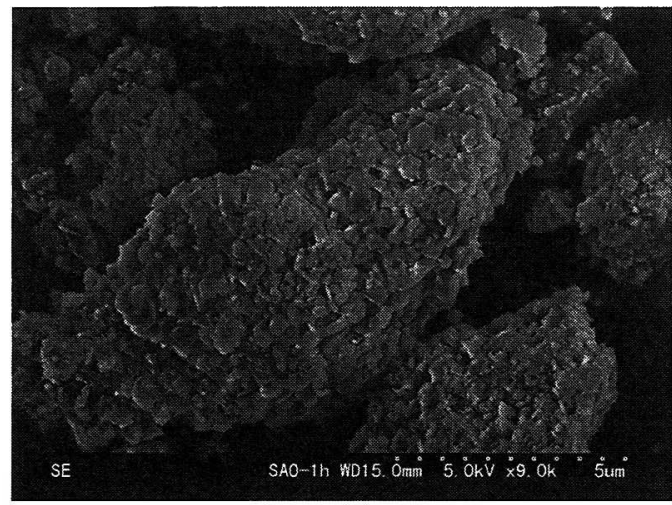

(b)

Fig. 8 SEM image of $\left(\mathrm{Sr}_{0.99} \mathrm{Eu}_{0.01}\right) \mathrm{Al}_{2} \mathrm{O}_{4}$ a) untreated

b) after $1 \mathrm{~h}$ immersion in water

ルミナであることが分かった。また，PL 測定の結果 から，含浸時間の経過とともにPL 強度が低下してお り，0.5時間経過で未含浸の $88 \% ， 1$ 時間経過で未含 浸の $61 \%$ まで低下した。さらに 5 時間経過後のサン プルについては，PL はほとんど検出できなかった。 $\mathrm{SEAO}$ 加水分解は, XRD の結果から次のような反応 メカニズムで起こっていると考えられる。

$$
3 \mathrm{SrAl}_{2} \mathrm{O}_{4}+6 \mathrm{H}_{2} \mathrm{O} \rightarrow \mathrm{Sr}_{3} \mathrm{Al}_{2}(\mathrm{OH})_{12}+2 \mathrm{Al}_{2} \mathrm{O}_{3}
$$

Fig. 1 に示すように, SEAOの母体構造は, $\mathrm{H}_{2} \mathrm{O}$ 分 子が侵人可能なほどの大きな空間を持っており,この 空間中心に存在している $\mathrm{Sr}$ イオンと反応して $\mathrm{Sr}$ $\mathrm{OH}$ となり，この化学反応が原因となり $\mathrm{AlO}_{4}$ 四面体 同士の結合が切れて結晶構造が崩壊したと考えられ る。PL 強度の低下は, 端的に言って SEAO 結晶構造 の崩壊に起因している。

一方, CEAS の耐水性実験結果を Fig. 7 に示すが,

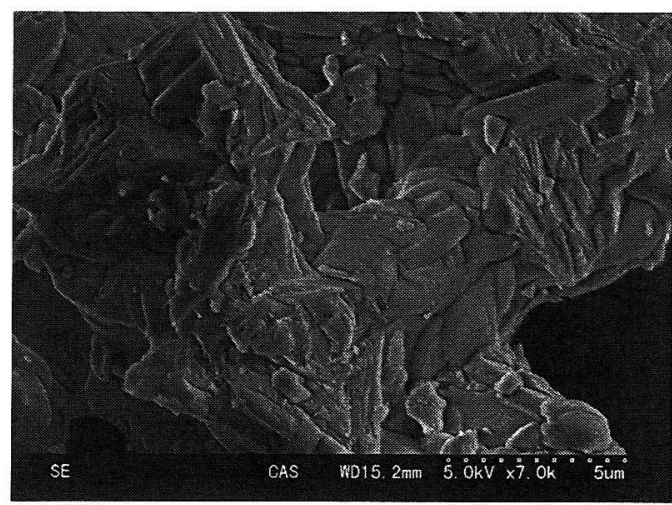

(a)

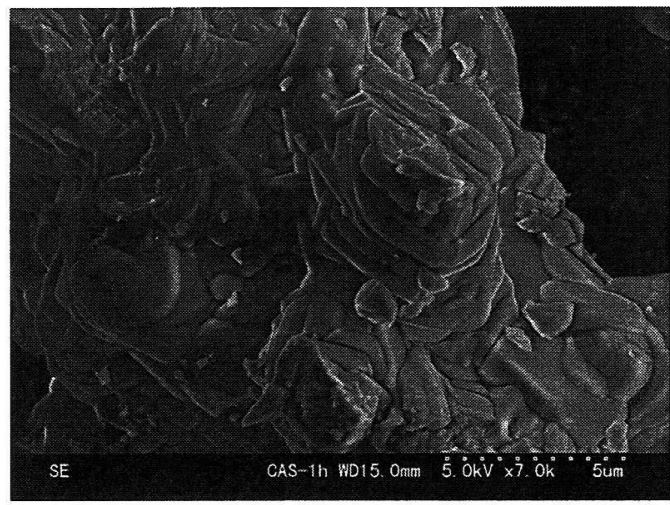

(b)

Fig. 9 SEM image of $\left(\mathrm{Ca}_{0.98} \mathrm{Eu}_{0.02}\right) \mathrm{Al}_{2} \mathrm{Si}_{2} \mathrm{O}_{8}$ a) untreated

b) after $1 \mathrm{~h}$ immersion in water

10 日間含浸させた後でも XRD パターンには変化は認 められず，メーンピークの強度はほとんど変わって いない。さらに，PL 測定の結果も XRD の結果と同 様な結果が得られており，含浸 10 日間後においても PL 強度は未含浸のサンプルとの差は認められず，加 水分解の兆候は観測できなかった。

CEAS が SEAO と比較して劇的に耐水性が高まっ た要因として，母体構造中の $\mathrm{SiO}_{4}$ 四面体の存在に一 因があると推測できる。すなわち， $\mathrm{Si}-\mathrm{O}$ の結合解離 エネルギー $(627 \mathrm{~kJ} / \mathrm{mol})$ は $\mathrm{Al}-\mathrm{O}$ の結合解離エネル ギー $(457 \mathrm{~kJ} / \mathrm{mol})^{18)}$ よりも高いので，母体構造の安 定性が高くなっていると考えられる。

含浸前後の結晶の形態変化を観察するため, SEM による表面観察を行った。Fig. 8 に，含浸前の SEAO 粉末試料之含浸 1 時間後の SEAO 粉末試料の SEM 写 真を示す。また，Fig. 9 に，含浸前の CEAS 粉末試料 と含浸 1 時間後の CEAS の粉末試料の SEM 写真を示 
Table 1 Change of relative mechanoluminescent intensity by water immersion

\begin{tabular}{c|c|c}
\hline Sample & Immersion time (h) & Relative ML intensity (\%) \\
\hline \multirow{2}{*}{$\left(\mathrm{Sr}_{0.99} \mathrm{Eu}_{0.01}\right) \mathrm{Al}_{2} \mathrm{O}_{4}$} & 0.5 & 0.3 \\
\cline { 2 - 3 } & 5 & 0 \\
\hline \multirow{2}{*}{$\left(\mathrm{Ca}_{0.98} \mathrm{Eu}_{0.02}\right) \mathrm{Al}_{2} \mathrm{Si}_{2} \mathrm{O}_{8}$} & 0.5 & - \\
\cline { 2 - 3 } & 240 & 100 \\
\hline
\end{tabular}

す。SEAO の場合，含浸前に観察されていた大きな 結晶粒子が, 含浸後非常に細かい粒子に変化し, 結晶 構造が崩壊したことが示唆される。CEASの場合は, 含浸したあとでも元の粒子形状を保ち，ほとんど変 わってない。これは，前述したXRD 及びPLによる 分析結果とも一致しており, CEASの構造が SEAO よ りも非常に優れた耐水性を有していることが表面形態 の観察からも示唆される。

Table 1 に，含浸後の各試料の ML 変化を示す。 SEAO の場合， 0.5 時間含浸させただけでもの ML 強 度は含浸前と比較して劇的に減少しており，5時間含 浸後のサンプルにいたっては，ML は全く検出できな かった。一方 CEAS の場合，ML 強度は10日間含浸 した後でももとの発光強度を維持し, SEAO より耐 水性が優れていることが実証できた。

今後は雨水や水性塗料など, 実際の使用条件での耐 水性の検討を加えていく予定である。

\section{4. 結言}

現在，実用化が進められている応力発光体 $\mathrm{SrAl}_{2} \mathrm{O}_{4}$ ： $\mathrm{Eu}^{2+}$ は加水分解を起こしやすく，耐水性を付与する ための後処理として複雑なコーティング処理を必要と する。本研究では，これまで開発してきた応力発光材 料の構造的特徴を抽出して材料設計の指針とすること で，新しい応力発光体を開発し，材料自体の耐水性を 大幅に改善することに成功した。耐水性の改善は，製 造プロセスの簡素化・コスト軽減に繋がるばかりでな く, 湿気の多い環境下での応力発光体の利用に道を開 くものである。例えば，現在，応力発光体塗料の作製 は有機溶媒系が中心だが, この耐水性の改善により水 溶媒系塗料への展開も可能である。また，今後生体内 への応力発光体の応用も視野に入っており, 例えば, 複雑な血流場によって生じる応力や衝撃波の生体組 織・細胞への影響に関して, 応力発光微粒子を用いた 診断技術の開発が期待されている。

\section{References}

1) Vij, D. R. : "Luminescence of Solid", Plenum Press, New York, pp. 361-389 (1998)

2 ) Brady, B. T. and Glen A. Rowell : "Laboratory Investigation of the Electrodynamics of Rock Facture", Nature, 321, 488-492 (1986)

3 ) Chandar, B. P. and A. S. Rathore : "Classification of Mechanoluminescence”, Cryst. Res. Technol., 30, 885896 (1995)

4 ) Butler, C. T. : "Room-Temperature Deformation Lu minescence in Alkali Halides", Phys. Rev., 141, 750-757 (1966)

5 ) Xu, C. N., T. Watanabe and M. Akiyama : "Direct View of Stress Distribution in Solid by Mechanoluminscence", Appl. Phys. Lett., 76, 2414-2416 (1999)

6 ) Xu, C. N., X. G. Zheng, M. Akiyama and K. Nonaka : "Dynamic Visualization of Stress Distribution by Mechanoluminescence”, Appl. Phys. Lett., 76, 179-181 (2000)

7 ) Xu, C.N., T. Watanabe, M. Akiyama and X.G.Zheng : "Artificial Skin to Sense Mechanical Stress by Visible Light Emission”, Appl. Phys. Lett., 74, 1236-1238 (1999)
8 ) Wang, X. S., C. N. Xu, H. Yamada, K. Nishikubo and X. G Zheng: "Electro-Mechano-Optical Conversions in $\mathrm{Pr}^{3+}$ - doped $\mathrm{BaTiO}_{3}-\mathrm{CaTiO}_{3}$ Ceramics", Adv. Mater., 17, $1254-1258$ (2005)

9 ) Akiyama, M., C. N. Xu and K. Nonaka : "Intense Visible Light Emission from Stress-activated $\mathrm{ZrO}_{2}$ : Ti", Appl. Phys. Lett., 81, 457-459 (2002)

10) Xu, C. N., H. Yamada, X. W. Wang and X. G. Zheng : "Strong elasticoluminescence from monoclinic-structure $\mathrm{SrAl}_{2} \mathrm{O}_{4}{ }^{\prime}$, Appl, Phys. Lett., 84, 3040-3042 (2004)

11) $\mathrm{Xu}, \mathrm{C}$. N. : "Koukido Ouryoku Hakkoutai no Kaihatsu to Sono Ouyou”, Shinnki Guromikkusu no Sekke Kinou Ouyou, pp. 291-304 (2005)

12) Kim, J. S., Y. N. Kwon, N. Shin and K. S. Sohn : "Visualization of Fracture in Alumina Ceramics by Mechanoluminescence", Acta Mater., 53, 4337 - 4343 (2005)

13) Zhang, J., Z. T. Zhang, Z. L. Tang and T. M. Wang: "Hydrolysis Mechanism and Method to Improve Water Resistance of Long After-glow Phosphor", Mater. Sci. Forum, 423-425, 147 - 150 (2003)

14) Imai, Y., R. Momoda, Y. Adachi, K. Nishikubo, Y. Ka 
ida, H. Yamada and C. N. Xu : "Water-resistant Surface-coating on Europium-doped Strontium Aluminate Nanoparticles", J. Electro, Chem. Soc., 154, J77J80 (2007)

15) Rodehorst, U., M. A. Carpenrer, S. Marion and C. M. B. Henderson: "Structure Phase Transition and Mixing Behaviour of the $\mathrm{Ba}$-aluminate $\left(\mathrm{BaAl}_{2} \mathrm{O}_{4}\right)-\mathrm{Sr}$ aluminate $\left(\mathrm{SrAl}_{2} \mathrm{O}_{4}\right)$ Solid Solution", Mineral. Mag., 67, 989-1013 (2003)
16) Im, W. B., Y-I. Kim, J. H. Kang and D. Y. Jeon : "Lu minescent and aging characteristics of blue emitting $\left(\mathrm{Ca}_{1-\mathrm{x}}, \mathrm{Mg}_{\mathrm{x}}\right) \mathrm{Al}_{2} \mathrm{Si}_{2} \mathrm{O}_{8}: \mathrm{Eu}^{2+}$ phosphor for PDPs application", Solid State Commun., 134, 717-720 (2005)

17) $\mathrm{Xu}, \mathrm{C} . \mathrm{N}$. : "Encyclopedia of Smart Materials", John Wiley \& Sons, pp. 190-201 (2002)

18) The Chemical Society of Japan: "Kagaku Binran", pp. II 315, Maruzan (2004) 